\title{
Painted plaster and glazed brick fragments from Achaemenid Pasargadae and Persepolis, Iran
}

Emily Aloiz $^{1 *+} \mathbb{B}$, Janet G. Douglas ${ }^{2+}$ and Alexander Nagel ${ }^{3+}$

\begin{abstract}
Background: Architectural fragments of decorated walls, floors, and columns excavated by Ernst Herzfeld (18791948) at the archaeological sites of Persepolis and Pasargadae in Iran are housed in the Freer Study Collection at the Freer Gallery of Art and Arthur M. Sackler Gallery (FSG), Smithsonian Institution in Washington, DC. Technical studies of these painted earthen plasters and glazed brick fragments were undertaken to enhance our knowledge of materials and technology of Achaemenid Persia between the late sixth and fourth centuries BCE. Initial analysis was done on the surface of the fragments using non-invasive X-ray fluorescence with a portable instrument. Polished crosssections were used to examine the layering stratigraphy of paints and glazes, and to undertake compositional analysis using scanning electron microscopy with energy-dispersive $X$-ray spectroscopy.

Results: Up to five layers of paint are present on the Pasargadae plaster, constituting the remnants of a geometric design. The plasters were bound with clay tempered with an organic material that has long since degraded, leaving small voids throughout. Pigments identified include Egyptian blue, malachite green, red ocher, and cinnabar red. The floor fragments from Persepolis were finished with a lime plaster and two layers of hematite-rich paint. The brick fragments from Persepolis were found to be composed of high-silica material similar to faience, which were decorated with alkaline glazes, including a yellow glazed colored with lead antimonate, gray glaze colored with magnesium and iron, and green glazed colored with copper.

Conclusions: While the exact ages of the finishes are unknown, a similar technology was employed to decorate Achaemenid architecture in its principle Iranian cities. The variety of materials excavated by Herzfeld demonstrates the ability of Achaemenid artisans to work with multiple mediums to create a polychromatic finish including that of glazed tiles, earthen plaster tempered with gravel, earthen plaster tempered with organic matter, colored earths, pigmented paints and lime plasters. The layering of these materials can be seen and analyzed in cross-section although surface deterioration is often quite severe. The analysis of the compositional data on the architectural fragments inform their long-term preservation at the FSG as well as at the sites themselves.
\end{abstract}

\section{Background}

Visual evidence has shown that the architectural facades of the palaces and tombs of the Achaemenid Persian Empire (ca. 550-330 BCE) were richly decorated with color [1-5]. At both Pasargadae and Persepolis,

\footnotetext{
*Correspondence: emilya@jmapreservation.com

${ }^{\dagger}$ All authors contributed equally to this work.

1 John Milner Associates Preservation, 3200 Lee Hwy,

Arlington, VA 22207, USA

Full list of author information is available at the end of the article
}

designated UNESCO World Heritage sites since 1979 and 2004 respectively, stone reliefs, excavated fragments, and paper pulp squeezes of inscriptions taken by archaeologists in the early 20th century bear visible paint remnants, evidence of a vibrant palette used to finish the surfaces of the monuments. Among these are 40 fragments of painted plasters and glazed bricks housed today in the Freer Study Collection at the Smithsonian Institution in Washington, DC. The fragments were excavated by a team led by archaeologist Ernst Herzfeld in 1923 and 1928, and were donated to the Freer Gallery of Art in 1947.

\section{Springer}

(c) 2016 Aloiz et al. This article is distributed under the terms of the Creative Commons Attribution 4.0 International License (http://creativecommons.org/licenses/by/4.0/), which permits unrestricted use, distribution, and reproduction in any medium, provided you give appropriate credit to the original author(s) and the source, provide a link to the Creative Commons license, and indicate if changes were made. The Creative Commons Public Domain Dedication waiver (http://creativecommons.org/ publicdomain/zero/1.0/) applies to the data made available in this article, unless otherwise stated. 
The ancient city of Pasargadae is located in the highland plain of Dasht-e Morghab ("Plain of the Waterbird") in Fars in southwestern Iran. It was the first capital of the Achaemenid Persian Empire, founded by Cyrus the Great after $550 \mathrm{BCE}$, and the famed leader's final resting place [6]. Palace P, Herzfeld's "Palast mit dem Pfeiler," from which the Pasargadae fragments in the Freer Study Collection originate, was first excavated with a series of narrow trenches in 1928 (Fig. 1). Fragments collected include twenty-two pieces of painted and unpainted earthen plaster. Persepolis, the prominent later capital of the Achaemenid Empire in Fars was founded by Darius I (c. 550-486 BCE) around $520 \mathrm{BCE}$, and is located $43 \mathrm{~km}$ southwest of Pasargadae, in the modern Marvdasht plain. The exact excavation location of the two painted fragments from a floor, and the six fragments of glazed brick from Persepolis can no longer be determined (Fig. 2). Both the painted fragments from Pasargadae and the glazed brick fragments from Persepolis were drawn in color in Herzfeld's excavation notebooks, which are now part of the Ernst Herzfeld Papers, Free Gallery of Art| Arthur M. Sackler Gallery Archives [7, 8].

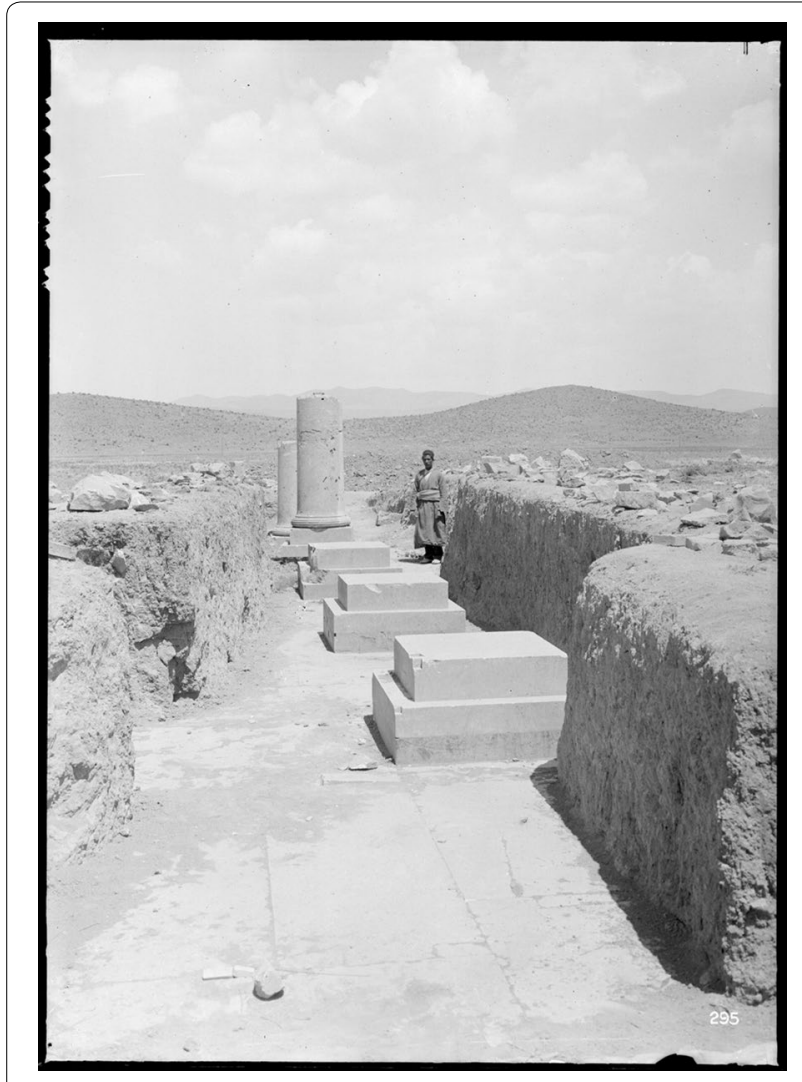

Fig. 1 Pasargadae, Palace P during excavation (The Ernst Herzfeld papers. Freer Gallery of Art and Arthur M. Sackler Gallery Archives. Smithsonian Institution, Washington, D.C. FSA_A.6_04.GN0295)

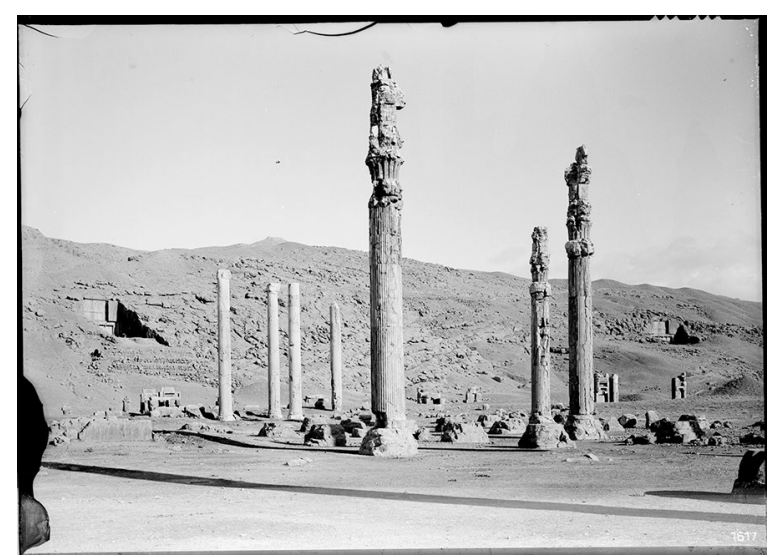

Fig. 2 Persepolis, during excavations (The Ernst Herzfeld papers. Freer Gallery of Art and Arthur M. Sackler Gallery Archives. Smithsonian Institution, Washington, D.C. FSA_A.6_04.GN.1617)

Analysis of the fragments was undertaken to document the materials and methods used to create the polychromatic finishes. Deterioration and friable paint layers made this work challenging. Comparison of Herzfeld's excavation notes and photographs to the actual fragments shows that deterioration not only took place during burial and excavation, but is ongoing, as larger pieces continue to degrade and pigment particles are lost. Thus, documentation is imperative. Portable X-ray florescence (pXRF) was used as a non-destructive method to analyze the surface composition. Due to the deterioration of the surfaces and the inability to isolate paint layers, crosssections were created using small samples of selected fragments, which were used to document the stratigraphies visually and with SEM/EDS.

\section{Results and discussion}

\section{Painted plaster}

Many of the earthen plaster fragments excavated at palace $\mathrm{P}$ at Pasargadae are finished with paints. Two fragments have a single paint layer, whereas seven are finished with a geometric design of multiple colors which may have been applied to the columns in the central hall. The geometric designs have at least five distinct layers of colored finish above the plaster substrate (Fig. 3). The Pasargadae plasters and paints are distinct from the Persepolis floor material in texture, appearance and composition. A summary of the materials and colorants identified is provided in Tables 1 and 2.

The Pasargadae paints were applied to a substrate of earthen plaster. The plaster is distinguished from the paint layers due to its thickness and presence of larger aggregate. While the current fragments' plasters are up to $4 \mathrm{~cm}$ thick, the original thickness was much greater 


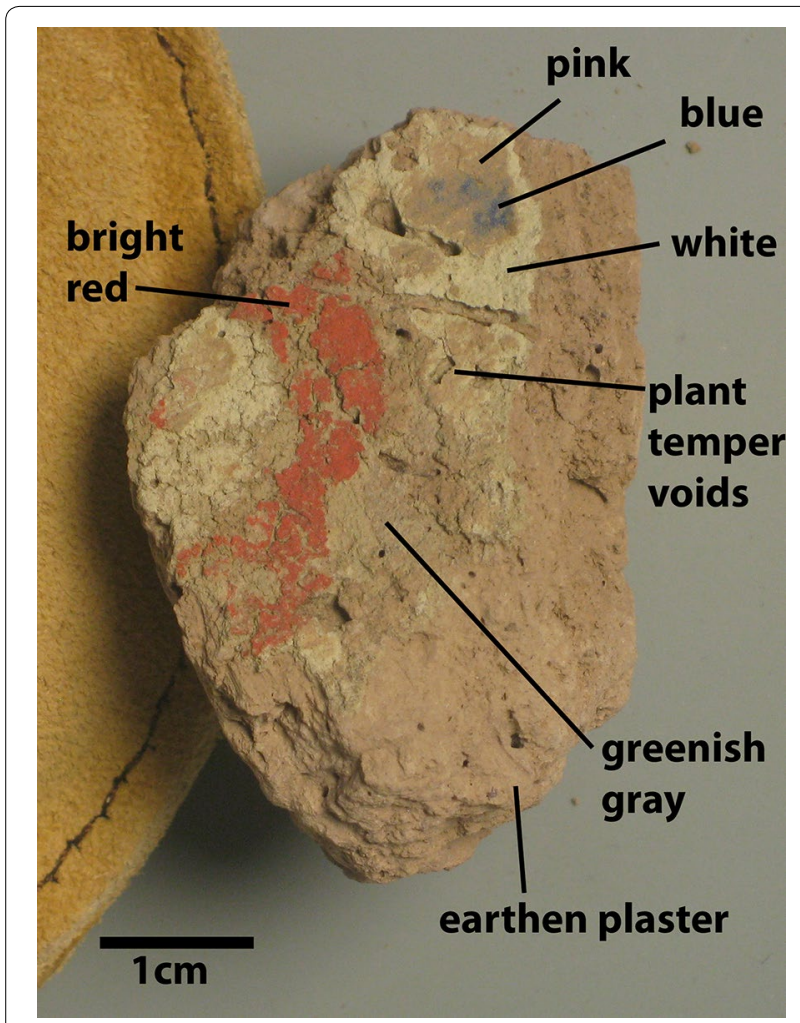

Fig. 3 Fragment FSC-A-1d with remnants of five paint layers as well as the earthen plaster substrate

as seen in an image taken after excavation now located in the Freer archives (Fig. 4). The plaster is quite friable, compounded by voids left throughout the plaster due to the loss of degraded plant temper. This organic temper may have been composed of chaff or similar material added to reinforce the plaster and control shrinkage.

The plaster from Pasargadae contains a fine-grained aggregate with all grains less than $0.25 \mathrm{~mm}$ and heterogeneous in color and shape surrounded by a brownish pink matrix. Analysis by pXRF identified iron, as well as calcium, strontium, copper and rubidium in two plaster fragments, likely from the clay binder as well as the aggregate. SEM/EDS of the four Pasargadae plaster cross-sections showed the characteristic elements of a mixture of clays including carbon, oxygen, magnesium, aluminum, silicon, potassium and calcium and iron. This indicates the presence of heterogeneous iron-containing clay, but not the type of clay. The clay likely acts as a binding material, and the iron gives the plaster a characteristic pink color.

Seven of the earthen plaster fragments from Pasargadae are coated with a grayish yellow green paint layer that is $0.3-0.5 \mathrm{~mm}$ thick. Analysis by pXRF showed the presence of iron, copper, calcium and strontium. SEM/EDS analyses of all five Pasargadae plaster cross-sections revealed multiple fine sub-rounded particles up to $7 \mu \mathrm{m}$ in diameter, composed primarily of magnesium, calcium and oxygen, and are consistent with dolomite. The particles are surrounded by a characteristic clay matrix of aluminum, magnesium, silicon, potassium, calcium, and iron. Most likely this layer is colored with the naturally green-tinted clay, montmorillonite. A similar paint was noted by Schmidt on the walls of the treasury at Persepolis that was found to be composed of clay [9]. The similar wall treatment suggests the two Achaemenid cities shared their colors and techniques for decorating architecture. However, at Pasargadae, the grayish yellow green paint was covered with additional paint layers to create a decorative pattern.

On five of the Pasargadae plaster fragments, a white layer was applied over the grayish yellow green layer. Herzfeld's excavation notes indicated the white layer was an exposed part of a three-color design; however, the white on the fragments is covered with pink paint [7]. In cross-section the white layer was thin, $0.1-0.25 \mathrm{~mm}$ thick. SEM/EDS of the cross-section of fragment FSC-A1i showed the platy morphology typically found in sheet silicates, as well as the presence of silicon, aluminum and calcium with trace amounts of potassium and magnesium. This evidence suggests the white paint is composed primarily of a mixture of muscovite and kaolinite.

Two painted plaster fragments, FSC-A-3a and FSCA-3b, were excavated at Persepolis and concluded by

Table 1 Painted plaster fragment samples studied in cross-section

\begin{tabular}{lll}
\hline $\begin{array}{l}\text { Freer study collection } \\
\text { accession no. }\end{array}$ & Original site location & Material \\
\hline FSC-A-1i & Pasargadae, building P (rubble) & Moderate blue and black paints; earthen plaster \\
& Pasargadae, building P (rubble) & Moderate blue and black paints; earthen plaster \\
& Pasargadae, building P, plastered column & Moderate red and grayish yellow green paint; earthen plaster \\
FSC-A-3C & Pasargadae, building P, plastered column & Light yellowish pink, white, grayish yellow green paint; earthen plaster \\
FSC-A-3a & Pasargadae, building P (rubble) & Moderate yellowish green and moderate blue paint; earthen plaster \\
& Persepolis, floor & Dark red paint; white plaster \\
\hline
\end{tabular}


Table 2 Summary of identified paint colorants on plaster fragments [11], Kelly and Judd 1976 [33]

\begin{tabular}{|c|c|}
\hline Color (Munsell color notation) & $\begin{array}{l}\text { Colorants identified from the } \\
\text { analytical evidence }\end{array}$ \\
\hline Moderate red (7.5R 5/8) & Cinnabar, HgS \\
\hline Dark red (5R 5/4-5R 3/4) & Hematite, $\mathrm{Fe}_{3} \mathrm{O}_{4}$ \\
\hline Light yellowish pink (5YR 9/2) & Hematite, $\mathrm{Fe}_{3} \mathrm{O}_{4}$ \\
\hline Moderate blue (10B 5/6) & $\begin{array}{l}\text { Cuprorivaite, } \mathrm{CaCuSi}_{4} \mathrm{O}_{10} \text { (Egyptian } \\
\text { blue) }\end{array}$ \\
\hline $\begin{array}{l}\text { Moderate yellowish green } \\
(10 \mathrm{GY} 6 / 6)\end{array}$ & Malachite, $\mathrm{Cu}_{2} \mathrm{CO}_{3}(\mathrm{OH})_{2}$ \\
\hline Yellowish white (5Y 9/2) & $\begin{array}{l}\text { Muscovite, } \mathrm{KAl}_{2} \cdot\left(\mathrm{AlSi}_{3} \mathrm{O}_{10}\right) \cdot(\mathrm{F}, \mathrm{OH})_{2} \\
\text { and/or kaolinite, } \mathrm{Al}_{2} \mathrm{Si}_{2} \mathrm{O}_{5}(\mathrm{OH})_{4}\end{array}$ \\
\hline Grayish yellow green ( $5 G Y 7 / 2$ ) & $\begin{array}{l}\text { Montmorillonite clay, }(\mathrm{Na}, \mathrm{Ca})_{0.33}(\mathrm{Al} \text {, } \\
\mathrm{Mg}_{2} \cdot\left(\mathrm{Si}_{4} \mathrm{O}_{10}\right) \cdot(\mathrm{OH})_{2} \cdot n \mathrm{H}_{2} \mathrm{O}\end{array}$ \\
\hline
\end{tabular}
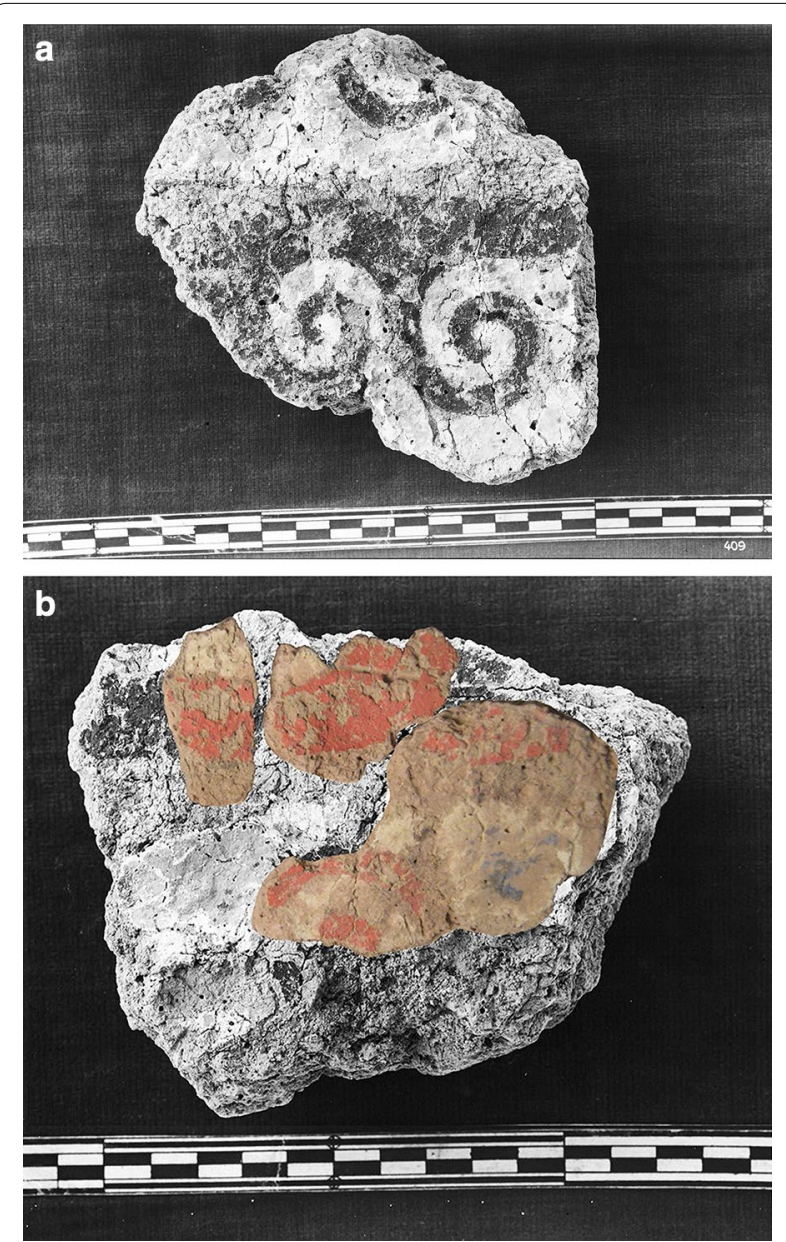

Fig. 4 Painted plaster fragment in the Freer study collection: a fragment photographed between 1928 and 1947, b fragments FSC-A-2A, FSC-A-2b, FSC-A-2d (in color) overlain on early photograph. (The Ernst Herzfeld papers. Freer Gallery of Art and Arthur M. Sackler Gallery Archives. Smithsonian Institution, Washington, D.C. FSA_A.6_04. GN.0409)
Herzfeld to be part of a floor. The finish paint layer is a deep red over a white layer on a pink plaster substrate. The plaster does not display voids indicative of a plant temper, but instead contains stone aggregate up to $0.75 \mathrm{~cm}$ in diameter. These stones would serve to control shrinkage, but also to impart compressive strength to the floor. The Persepolis plasters have lost little to no visible surface area from the historic photographs and are considerably more stable than the plasters from Pasargadae.

The craftsmen applied a white paint layer to the plasters at Persepolis, which was then covered with red paint. The Persepolis floor white is thicker than other paints examined in cross-section, measuring $2-5 \mathrm{~mm}$ and contains aggregate particles measuring up to about $0.5 \mathrm{~mm}$ in diameter as seen in fragment FSC-A-3a (Fig. 5). The thickness of this layer and large aggregate size indicate this layer was likely applied to create a smooth surface over the plaster on which to apply the paint.

The yellowish white layer was identified by SEM/EDS as calcium carbonate based on the primary presence of calcium, carbon and oxygen. Other particles in the layer are high in silicon and oxygen, indicating quartz sand grains. The calcium carbonate binder appears to be the product of a lime cycle, during which a limestone is crushed and burned to create lime, calcium oxide. The lime is then mixed with water to make a slaked lime paste that is applied to the building where it can slowly absorb carbon dioxide from the air and return to calcium carbonate. Crushing and burning the stone is a labor and fuel intensive process, requiring much more effort than the creation of clay plasters, but the resulting finish is more durable. Recent excavations west of the platform of Persepolis uncovered evidence of a kiln in which burnt

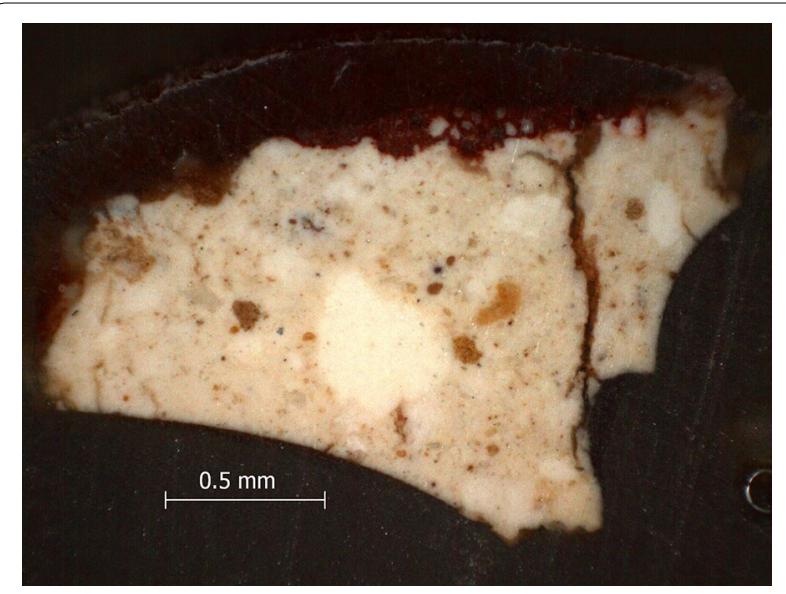

Fig. 5 Cross-section of painted plaster fragment FSC-A-3a in reflected light showing a layer of white lime with aggregate beneath a dark red pigment layer composed of hematite 
animal bones produced a ground material which was likely used to create an additional white paint on the terrace complex [10,11].

Three distinct red colored pigments were analyzed during this study. Both the moderate red as well as a light yellowish pink can be seen in fragment FSC-A-1d from Pasargadae. The dark red from the floor fragment was found to contain high levels of iron by both pXRF and SEM/EDS, suggesting that the pigment used was hematite. This paint was applied as a thick paint layer $(0.5-1 \mathrm{~mm})$ with aggregate to give it strength over the white lime plaster. Hematite has also been identified on lime plaster floors in the Palace of Darius at Persepolis, and on limestone masonry in non-visible areas at both Persepolis and Pasargadae [3]. It has been suggested that hematite, an abundant and inexpensive pigment, was used to create guidelines for builders placing stone [1]. The use of various analytical techniques-Raman microprobe, XRD, pXRF and SEM/EDS have obtained similar results supporting hematite as a common pigment in the Achaemenid Persian world.

The moderate red color is still vibrant on sixteen fragments of earthen plasters from Pasargadae. The layer thickness of the red paint in cross-section is $5 \mu \mathrm{m}$ or less. The pigment's particle size is approximately $1-3 \mu \mathrm{m}$, with many voids between the particles. The red paint likely had an organic binder that has deteriorated leaving only a fragile layer of pigment particles behind. Analysis by pXRF showed this paint layer has a high mercury content. Iron was identified as well, although it was only slightly higher than the iron content in the earthen plaster substrate. SEM/EDS analysis identified strong peaks for mercury and sulfur in almost equal atomic proportions, indicating the pigment is cinnabar, or mercuric sulfide (HgS), a naturally-occurring mineral. Cinnabar has been previously identified as a pigment at both Persepolis and Pasargadae [3].

A light yellowish pink paint layer was found in the Pasargadae geometric design's stratigraphy. Analysis by pXRF indicated copper, iron, calcium, strontium, mercury and rubidium. In cross-section the layer is less than $0.5 \mathrm{~mm}$ thick with sub-elongate particles less than $1 \mu \mathrm{m}$ in diameter. The SEM/EDS data showed the strong presence of iron-rich areas, likely the source of the light red color. The presence of aluminum, silicon, and magnesium in the SEM/EDS indicates the presence of clay. The results suggest this layer was a naturally occurring pink clayey soil. The clay and hematite $\left(\mathrm{Fe}_{2} \mathrm{O}_{3}\right)$ mixture in this paint suggest it can be categorized as red ocher. Not enough information was available to identify the type of clay present, although the elemental composition suggests the clay of the illite- or smectite-groups, rather than kaolinite.
Six earthen plaster fragments from Pasargadae displayed traces of a moderate blue paint. In the geometric design the blue paint was exclusively applied over the light yellowish pink paint layer discussed earlier. Additional fragments from Pasargadae have remains of blue paint-some with a homogeneous blue and another with a mixture of green and blue particles. Analysis by XRF was conducted on the blue from the geometric design and the fragment with a homogeneous blue layer-FSCA-1f. Both blues appeared similar with the presence of copper, iron and calcium.

SEM/EDS of pigment particles in cross-sections indicated calcium, copper, silicon and oxygen in the atomic ratio of approximately 1:1:5:10 which is close to the calcium copper silicate formula of the mineral cuprorivaite, $\mathrm{CaCuSi}_{4} \mathrm{O}_{10}$ known as Egyptian blue. This material is quite durable as a pigment, and will not react to acids or oxidize to a different color like azurite oxidizes to green malachite [12]. Significant as the first known synthetic pigment, Egyptian blue was created by mixing silica, lime, copper and an alkali, likely using a two phase firing process [13]. This blue pigment has been previously identified at three locations in Persepolis [3, 9], but this is the first time it has been identified at Pasargadae.

In cross-section, a black layer was revealed underneath the blue paint, less than $5 \mu \mathrm{m}$ thick (Fig. 6). It was observed in two cross-sections taken from FSC-A1i, which did not appear to be a part of the geometric design. The black colorant is likely carbon from readily available soot from the burning of organic materials. We hypothesized that this layer was used as a primer layer to darken the blue paint layer above it, or that it was a guide line used to trace a pattern. The fact that it was found in two separate cross-sections suggests the former.

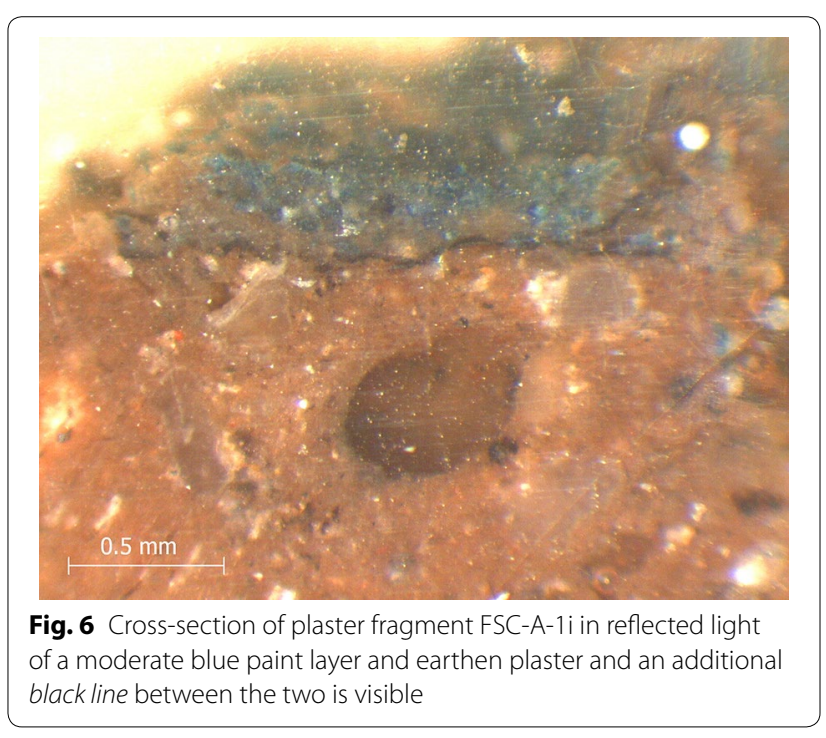


Only one fragment from Pasargadae, FSC-A-3c, had moderate yellowish green pigment and it was mixed with a moderate blue pigment, similar to the blue found elsewhere. Under magnification the green particles did not form a continuous paint layer, but instead consisted of tiny patches of pigment particles on the plaster indicating that most if not all the binder had been lost. Compositional analysis by pXRF was conducted on an area where the blue and green particles were mixed and another area that was mainly green. Comparison of the areas revealed identical peaks for iron and calcium, likely from the plaster substrate, and copper.

SEM/EDS analysis of green pigment particles showed the presence of copper, carbon and oxygen, indicating the green pigment is the mineral malachite $\left[\mathrm{Cu}_{2} \mathrm{CO}_{3}(\mathrm{OH})_{2}\right]$. Particles could be seen with SEM/EDS to be associated with quartz as overgrowths, indicating that the malachite is of natural origin, rather than a synthetic pigment. One possible geologic source of the malachite is the copper mines recently excavated in the Fars Province of Iran [4]. Malachite has previously been identified as a pigment at Persepolis [3] but further research would be required to investigate the geologic origin of the malachite.

The blue and the green particles were thoroughly mixed, and it was not possible to ascertain with reflected light microscopy if the green was above the blue, underneath it or possibly a product of oxidation of the blue. Even though blue azurite naturally oxidizes to malachite, elemental analysis showed that the blue was Egyptian blue, not azurite, indicating that the two pigments were originally distinct colors. Based on the lack of apparent stratigraphy using SEM, it can be postulated that the malachite green and blue pigments were intentionally mixed to create a blue and green color.

\section{Glazed brick fragments}

The ancient Near East has a long tradition of glazing architectural bricks, traced to the time of Kassite rule of the Iranian highlands from 1750 to $1170 \mathrm{BCE}$ [14] and the 4th millennium BCE in Egypt [13]. In the Achaemenid world glazed bricks were prevalent in lowland Susa, where the raw materials for brick making are abundant. Archaeological evidence suggests that Susa in the heartland of Elam had a long tradition in glazing technologies [15]. Recent years have seen increased interest in research on glazed bricks excavated at Late Babylonian materials from Babylon and Borsippa in the Mesopotamian heartlands still visible during Achaemenid rule [1618]. While the city of Achaemenid Susa was an important center of Achaemenid Persia, textual evidence suggests brick makers in the city at the time of Darius I were Babylonian [14, 19]. Furthermore, Egyptian craftsmen have been employed in the construction of Persepolis [20].
These examples of foreign artisans at Achaemenid Persian sites warrant further investigation of the relationships of the materials and technologies to other locations in the ancient Near East.

Ancient Near East glazes typically contain varying amounts of lime, natron or plant ash, silica and inorganic colorants. Common additives include lead as a flux and calcium antimonate as an opacifier. A flux is a non-coloring metallic oxide that lowers the melting temperature of the glaze and reacts when heated with acidic ingredients to produce glass. The opacifier makes the glaze less translucent. The alkaline content gives it clarity and brightness. Matson and others have shown that the alkalis used in the ancient Near East were created from plant ashes, and the resulting composition would vary widely depending on the type of plant burned [16]. These are also easily lost in a burial environment.

Four glazed brick fragments excavated by Herzfeld from Persepolis were analyzed, and a summary of their cross-sections and identified glaze colorants is given in Tables 3 and 4. The fragments are too thin to be structural bricks (approx. 1-1.5 $\mathrm{cm}$ ) although the original depth of the intact bricks is not known. They may have been decorative tiles applied to a structural surface. The fired brick bodies are covered with colored glazes

Table 3 Glazed brick fragment samples studied in crosssection

\begin{tabular}{|c|c|c|}
\hline $\begin{array}{l}\text { Freer study collection } \\
\text { accession no. }\end{array}$ & $\begin{array}{l}\text { Original site } \\
\text { location }\end{array}$ & Material \\
\hline FSC-A-3e & Persepolis & $\begin{array}{l}\text { White ridge, white glaze; } \\
\text { faience brick }\end{array}$ \\
\hline \multirow[t]{3}{*}{ FSC-A-3d } & Persepolis & Pale yellow glaze \\
\hline & Persepolis & $\begin{array}{l}\text { Gray ridge, moderate } \\
\text { yellowish green and } \\
\text { pale yellow glazes }\end{array}$ \\
\hline & Persepolis & $\begin{array}{l}\text { Moderate yellowish } \\
\text { green glaze; faience } \\
\text { brick }\end{array}$ \\
\hline
\end{tabular}

Table 4 Summary of identified colorants on glazed brick fragments (see [32, 33] for Munsell color notation)

\begin{tabular}{|c|c|}
\hline Color (Munsell color notation) & $\begin{array}{l}\text { Glaze colorants identified } \\
\text { from the analytical evidence }\end{array}$ \\
\hline $\begin{array}{l}\text { Glaze-yellowish pink to pale } \\
\text { yellow }(2.5 \text { YR } 8 / 6-2.5 Y 9 / 4)\end{array}$ & $\begin{array}{l}\text { Lead antimonate, } \mathrm{Pb}\left(\mathrm{SbO}_{3}\right)_{2} / \\
\mathrm{Pb}_{3}\left(\mathrm{SbO}_{4}\right)_{2}\end{array}$ \\
\hline $\begin{array}{l}\text { Glaze_moderate yellowish green } \\
(10 \mathrm{GY} 6 / 6)\end{array}$ & Copper \\
\hline Raised line_-gray (N7.5) & Iron \\
\hline Raised line—white (10R 9/1) & Alkaline earth elements \\
\hline
\end{tabular}


separated from each other by raised lines as seen on brick fragment FSC-A-3d (Fig. 7). The composition of all four brick bodies is consistent with the silica-rich, clay-poor fired material similar to faience. The lack of lead as a flux indicates that the firing temperature of the brick body would have been higher than that of the colored glazes. However, the fragments are too small to determine their decorative scheme.

Previous research has shown that the brick bodies from Achaemenid sites differ from the composition of bricks in the Mesopotamia region. Glazed wall plaques from neoAssyrian sites and bricks from the neo-Babylonian period of Babylon were made with calcareous clays likely from the alluvial sediments between the Tigris and Euphrates $[16,21,22]$. In contrast, Achaemenid bricks were made in the faience technique [19], created by mixing sand or powdered quartz with lime or limestone and alkali in the form of natron or plant ashes [13,23]. A previous study of bricks from Persepolis suggested they were faience due to a composition low in alumina indicating a lack of clay in the body [21], as was also found in this study. The faience technology likely originated from Elam. Twelve glazed bricks from Elam were identified as faience by Caubet using pXRF, with less than $1.7 \%$ alumina and less than $2 \%$ iron oxides, in contrast to bricks from Assyria and Babylon with 12-14\% alumina and 4-7 \% iron oxides [23]. However, analysis of other brick bodies from Achaemenid Susa, the historic capital of Elam identified clays in the brick bodies $[24,25]$. More research is needed to understand the use and cultural implications of faience technology across the Achaemenid empire.

Raised lines on the surface of the brick bodies separate colored fields of glaze. These are consistently $2 \mathrm{~mm}$

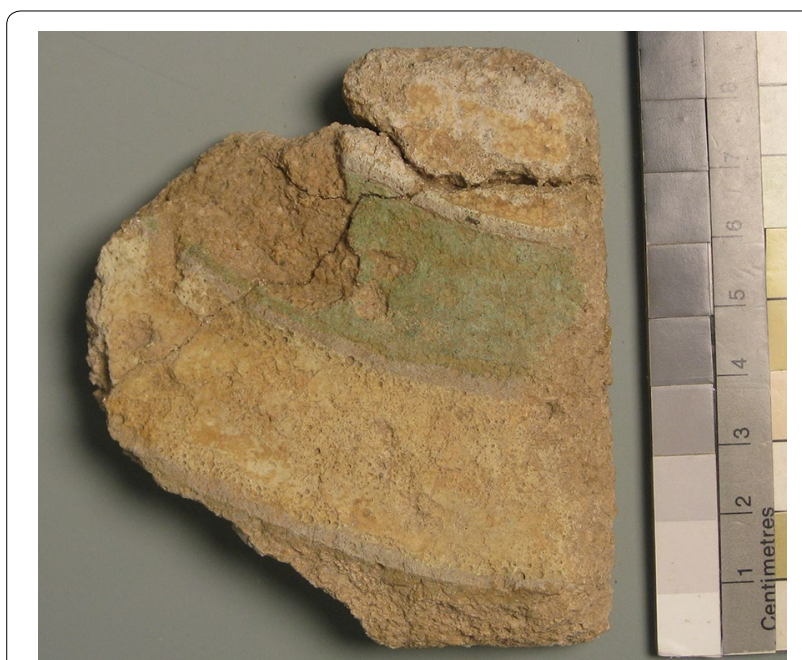

Fig. 7 A glazed brick fragment, FSC-A-3d, from Persepolis displaying colored glazes separated by glazed raised lines in thickness, but vary in height depending on the level of deterioration. They appear white to light gray in color. The white line can be seen in the cross section of FSC-A3e (Fig. 8). Microscopic examination of the raised lines in cross-section showed they are a distinct material in texture and particle size as compared to the brick body and the colored glazes.

SEM/EDS analysis of the white raised line showed typical clay elements such as silicon, oxygen, magnesium, and calcium whereas the gray line on fragment FSC-A-3d contained additional elements of lead, copper, and iron. Low lead levels in both raised lines suggest they would have had a higher melting point than the colored glazes. All flat glazes between the raised lines were found to contain lead as a flux. In this case, the glazes would become liquid upon firing at lower temperatures and spread between the raised lines which would have remained solid, acting as an enclosure. This technique has been documented at Susa [23, 24, 25].

All colored glazes were deteriorated with surface loss, chemical deterioration and cracking at a microscopic
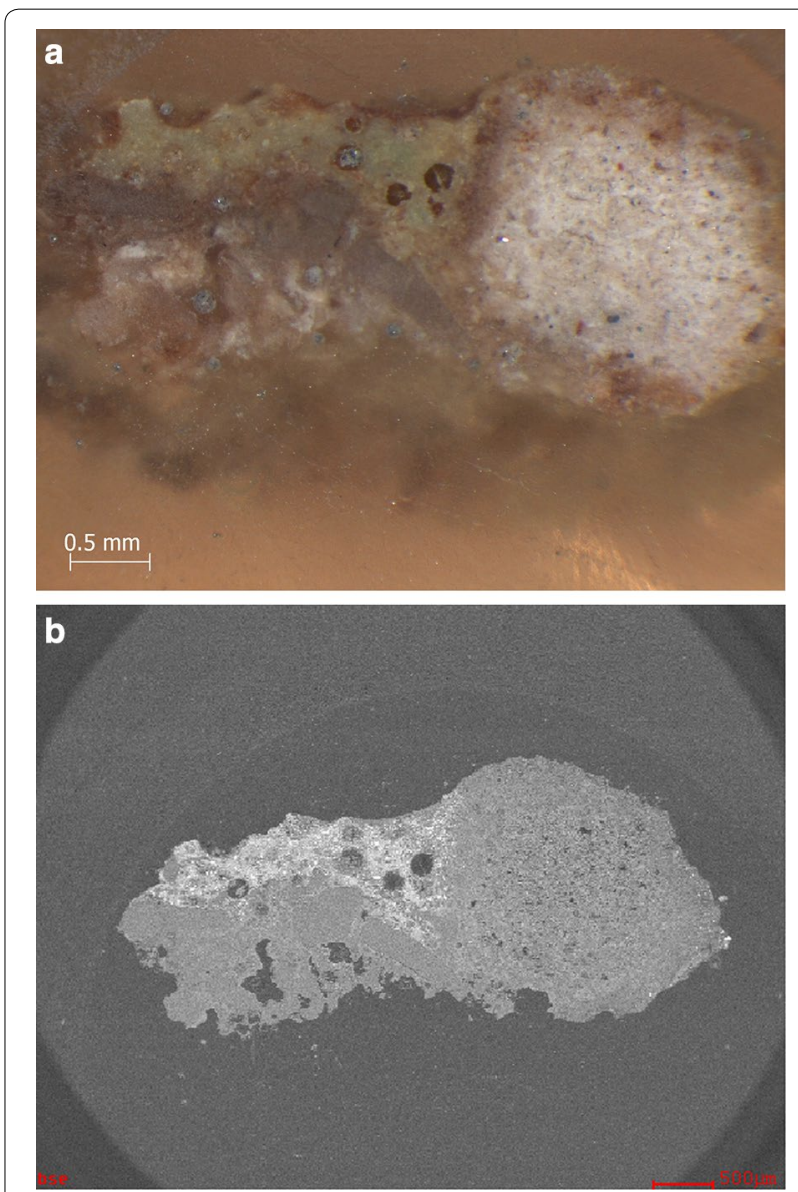

Fig. 8 A cross-section showing brick fragment FSC-A-3e. A pale yellow glaze and white raised line over the faience brick body can be seen in both reflected light (a) and SEM backscattered electron image (b) 
level. Indents on the surfaces are likely from bubbles within the glaze created during firing. Deterioration of the glaze surface has exposed the bubbles and left an indented, rough surface that traps dust. Additional complications from previous repairs completed before their arrival at the Freer such as yellowed adhesive and gray parge encourage deterioration.

The pale yellow glaze on fragment FSC-A-3d was analyzed with PXRF and SEM-EDS in cross-section. The tests indicated the presence of lead, antimony, silicon and oxygen. The coloring agent was probably yellow lead antimonate, which is consistent with other studies conducted on ancient Near East yellow glazes. Previously studied yellow glazes, without exception, were found to contain lead antimonate, which acted as a colorant and an opacifier [14, 16, 17, 22-24, 26, 27]. Like a pigment, these opaque antimonate particles are bound in a matrix of glass that contains lead and silica (Fig. 9).

A moderate yellowish green colored glaze is present on one brick fragment FSC-A-3d from Persepolis. The glaze was found to be up to $0.4 \mathrm{~mm}$ thick, although it would have been thicker in its original state. Lead, copper, antimony, strontium, iron and calcium were found by pXRF in the glaze. SEM/EDS analysis confirmed the presence of a significant amount of copper as a glaze coloring agent. Yellow lead antimonate particles in the green matrix presumably added as an opacifier and to give a deeper green color to the copper oxide which would appear more turquoise without it. Underneath the green glaze a large silica sand grain (1 $\mathrm{mm}$ in length) that may be the remnant of an engobe layer (Fig. 10). Many other studies analysis of both turquoise and green glaze have found copper as

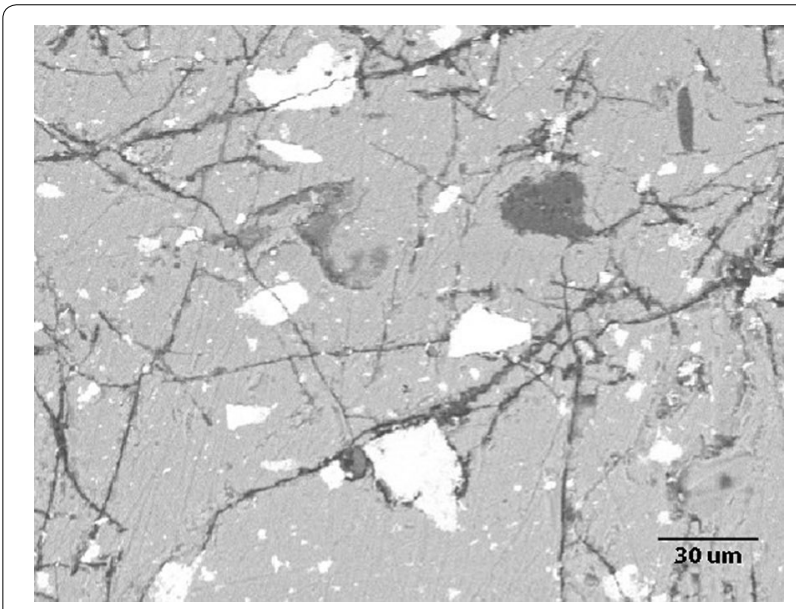

Fig. 9 SEM backscatter image of the pale yellow glaze from brick fragment FSC-A-3d in cross-section. The dark gray particles are unreacted silica; the white particles are lead antimonate, which give the glaze its yellow color. The particles are bound in a glassy matrix containing lead, silicon and oxygen

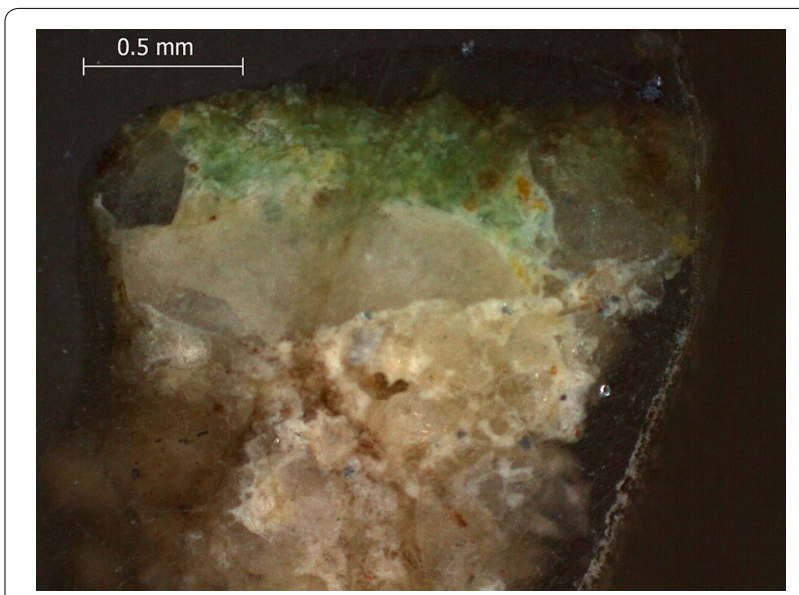

Fig. 10 Cross-section showing a moderate yellowish green glaze on brick fragment FSC-A-3d. Pale yellow lead antimonate is visible within the green glaze and an unreacted silica particle can be seen between the glaze and faience brick body

the colorant including Achaemenid Susa [23-25], NeoAssyrian Khorsabad [23], Nineveh [27], and Neo-Babylonian Babylon [16].

The white glazed brick fragment FSC-A-3e is heavily deteriorated, but the presence of oxygen, antimony, lead and calcium found by SEM/EDS suggests the presence of calcium antimonate as well as particles of lead antimonate. Calcium antimonate would act as a white colorant and the lead antimonate as an opacifier. Similar to the green glaze, the white glaze was separated from the brick body by particles of unreacted silica up to $1.5 \mathrm{~mm}$ in length that appear to be part of an engobe layer. Calcium antimonate has also been found as a white glaze colorant in Achaemenid Susa [23], neoBabylonian Babylon [17], and both neo-Assyrian sites of Nimrud [22], and Nineveh [27]. One study of Achaemenid Susa brick fragments found sodium antimonate as a white colorant [24].

\section{Conclusions}

The composition of fragments of painted plasters and glazed bricks studied here offers a glimpse of the decorative finishes of Pasargadae and Persepolis. Our research builds upon previous studies focusing on the analysis of materials excavated at Achaemenid Persian sites, including recent research on decorated materials from Susa. While our understanding of the state-of-the-art technology used in Iran between the mid-sixth and late fourth centuries BCE has much improved in recent years, fragments excavated over 88 years ago still have the potential to yield valuable insights.

The study of archival material presents the opportunity to re-address unresolved questions and open up new research inquiries. These findings reinforce pigments, 
glazes and plasters previously identified at Achaemenid sites and demonstrate the connectedness of the appearance of monumental architecture across the Achaemenid Empire. Many questions still remain. Why and when were faience bricks used and what are the cultural implications of the use of different brick technologies? What are the geologic sources of the pigments and colorants and can they be connected with better preserved painted and glazed fragments from Susa and Mesopotamian sites such as Babylon and Borsippa?

Traces of deteriorated finishes offer a small window into the colors and designs employed on a large structure, but their fragility exemplifies the need to document them as much as possible. The characterization of the microstructure and identification of deterioration will inform the fragments' long-term preservation at the FSG. Only recently, an entire facade of glazed bricks has been excavated near the Persepolis citadel [28], highlighting the need for conservation of the newly excavated Achaemenid finishes. By the examination and documentation of architectural finishes, this study strives to fulfill one of the objectives of Herzfeld's initial excavation plans' and more recent calls to protect and preserve the fragile Achaemenid remains at the sites of Pasargadae and Persepolis [6, 29].

\section{Methodology}

pXRF was used as a rapid, qualitative, and non-invasive method for identifying elemental composition of the surfaces of the fragments. A Bruker Tracer III-IV handheld pXRF instrument was used with an accelerating voltage of $40 \mathrm{kV}$, and a collection time of $90 \mathrm{~s}$.

Cross-sections of select small samples ( $<3 \mathrm{~mm}$ length) were prepared according to a method that requires minimal sampling [30]. The samples were embedded in Tra-Bond F113 epoxy, sectioned, and dry polished with silicon carbide grinding paper to minimize loss of watersoluble particles. Particularly porous samples were consolidated with cyanoacrylate during the polishing process as necessary. Finished cross-sections were photographed using a Leica EC3 camera mounted on a Wild Heerbrugg optical microscope using reflected light at magnifications of $12-50 \times$, and a Leica DMLM optical microscope from $50-200 \times$ in reflected and ultraviolet light.

The cross-sections were carbon-coated for SEM/EDS, and the analysis carried out with a FEI/Philips TMP XL30 SEM equipped with EDAX Genesis EDS at $25 \mathrm{kV}$, and a probe current of $10 \mathrm{nA}$.

Petrographic analysis was done with the Leica DMLM optical microscope in transmitted light. Optical dispersions of detached pigment particles in polarized light were used to verify the identification of cinnabar, hematite and malachite pigments.

\section{Further research suggestion}

Potential for further analysis of the painted plaster fragments might include using imaging techniques to detect the luminescence of Egyptian blue [31] and its spatial occurrence on the fragments.

\section{Abbreviations}

F|S: Freer Gallery of Art and Arthur M. Sackler Gallery; MCl: Smithsonian's Museum Conservation Institute; pXRF: portable X-ray fluorescence spectrometry; SEM/EDS: scanning electron microscopy with energy dispersive $X$-ray spectroscopy.

\section{Authors' contributions}

EA studied the fragments, performed the analyses, undertook data interpretation, and drafted the manuscript. JD oversaw data acquisition, contributed to data interpretation as well as revised the paper. AN contributed to the study concept, historical background, and revised the paper. All authors read and approved the final manuscript.

\section{Author details}

${ }^{1}$ John Milner Associates Preservation, 3200 Lee Hwy, Arlington, VA 22207, USA. ${ }^{2}$ Smithsonian Institution, Museum Conservation Institute, 4210 Silver Hill Road, Suitland, MD 20746, USA. ${ }^{3}$ Smithsonian Institution, National Museum of Natural History, 10th St. \& Constitution Ave. NW, Washington, DC 20560, USA.

\section{Acknowledgements}

The authors would like to thank Blythe McCarthy, Senior Scientist in the Department of Conservation and Scientific Research, Freer Gallery of Art and Arthur M. Sackler Gallery, for her helpful discussion and support for this project. Thanks to Melvin Wachowiak, Senior Conservator at the Smithsonian's Museum Conservation Institute who assisted with cross-section preparation and microphotography. The authors also express their gratitude to the F/S Archives for historic images and Richard Livingston for suggestions to the manuscript. Fellowship funding for this 2-month research project (January/ February 2013) was provided by the Smithsonian Office of Fellowships and Internships, the Smithsonian's Freer Gallery of Art and Arthur M. Sackler Gallery, and the Smithsonian's Museum Conservation Institute.

Competing interests

The authors declare that they have no competing interests.

Received: 28 August 2015 Accepted: 4 February 2016

Published online: 19 February 2016

\section{References}

1. Tilia AB. Studies and restorations at Persepolis and other sites in Fars, ii. Rome: IsMeo; 1978. p. 31-69.

2. Lerner J. The Achaemenid relief of Ahura Mazda in the Fogg Art Museum. Bull Asia Inst. 1971;2:19-35.

3. Stodulski L, Farrell E, Newman R. Identification of Ancient Persian pigments from Persepolis and Pasargadae. Stud Conserv. 1985;29(3):143-54.

4. Nagel A. Colors, gilding and painted motifs in Persepolis: approaching the polychromy of Achaemenid Persian architectural sculpture, c. 520-330 BCE. PhD Thesis. Ann Arbor: University of Michigan; 2010

5. Nagel A. Color and gilding in achaemenid architecture and sculpture. In: Potts D, editor. The Oxford handbook if Iranian archaeology. Oxford: Oxford University Press; 2013. p. 596-621.

6. Stronach D. Pasargadae: a report on the excavations conducted by the British Institute of Persian Studies from 1961 to 1963. New York: Clarendon Press; 1978.

7. Herzfeld E. The Ernst Herzfeld papers, Series 2: sketchbooks. Freer Gallery of Art and Arthur M. Sackler Gallery Archives. Washington: Smithsonian Institution; 1928. Subseries 2.02: Pasargadae: sketchbook 10: 9. 
8. Herzfeld E. The Ernst Herzfeld papers, series 2: sketchbooks. Freer Gallery of Art and Arthur M. Sackler Gallery Archives. Washington: Smithsonian Institution; 1923. Subseries 2.01: Persia: sketchbook 04: 59.

9. Matson FR. A study of wall plaster, flooring, and bitumen. In: Schmidt EF, editor. Persepolis, vol I: structures, reliefs, inscriptions. Chicago: University of Chicago Press; 1953. p. 285-8.

10. Askari Chaverdi A, Callieri P. The activities of the Iranian-Italian joint archaeological mission at Persepolis West (Fars, Iran). First results of the studies on the pottery of Achaemenid and post-Achaemenid age. In: Basello GP, Rossi A, editors. Persepolis and his settlements. Proceedings of the conference held in Viterbo, 16-17th December 2010. Naples: Università di Napoli "L'Orientale"; 2012. p. 100-22.

11. Askari Chaverdi A, Callieri P, Laurenzi Tabasso M, Lazzarini L. The archaeological site of Persepolis (Iran): study of the finishing technique of the bas-reliefs and architectural surfaces. Archaeometry. 2016;58(1):17-34

12. Gettens RJ, Stout GL. Painting materials, a short encyclopaedia. New York: Dover Publications Inc.; 1966.

13. Tite MS, Bimson M. Identification of early vitreous materials. In: Black J, editor. Recent advances in the conservation and analysis of artifacts. London: University of London Institute of Archaeology; 1987. p. 81-5.

14. Fukai S (trans. Crawford EB). Ceramics of ancient Persia. New York: Weatherhill; 1981.

15. Heim S. Glazed objects and the Elamite glaze industry. In: Harper P, Aruz J, Tallon F, editors. The royal city of Susa: ancient near eastern treasures in the Louvre. New York: Metropolitan Museum of Art; 1992. p. 202-10.

16. Matson FR. Glazed brick from Babylon-historical setting and microprobe analyses. In: Kingery WD, editor. Technology and Style: Ceramics and Civilization II. Ohio: Am Ceram Soc; 1986. p. 133-56.

17. Fitz SC. The coloured glazes of neo-Babylonian wall facings. Ceram Forum Int Berichte der Deutschen Keramischen Gesellschaft. 1982;59:179-8516.

18. Kaniuth K. Spätbabylonische Glasurziegelreliefs aus Borsippa. Mitteilungen der Deutschen Orientgesellschaft. 2013;145:53-82.

19. Moorey PRS. Ancient mesopotamian materials and industries: the archaeological evidence. Oxford: Clarendon Press; 1994.

20. Wasmuth M. Egyptians in Persia. In: Briant P, Chauveau M, editors. Organisation des pouvoirs et contacts culturels dans les pays de l'empire achéménide. Paris: Editions De Boccard; 2009. p. 133-41.
21. Dayton JE. Minerals, metals, glazing and man. London: Harrup; 1978.

22. Freestone IC. Technical examination of neo-Assyrian glazed wall-paintings. Iraq. 1991;53:55-8.

23. Caubet A. Faïences et matières vitreuses de l'Orient ancien. Paris: Éditions Snoeck/Musee du Louvre editions; 2007.

24. Razmjou S, Tite MS, Shortland AJ, Jung M, Hauptmann A. Glasierte Ziegel der achaemenidischen Periode. In: Stoellner T, Slotta R, Vatandoust A, editors. Persiens antike Pracht. Bergbau, Handwerk, Archaeologie. Exhibition Catalogue. Deutsches Bergbaumuseum Bochum: 2004. p. 382-93.

25. Holakooei P. A technological study of elamite polychrome glazed bricks at Susa, South-Western Iran. Archaeometry. 2014;56(5):764-83.

26. Holakooei P. A multi-spectroscopic approach to the characterization of early glaze opacifiers: studies on an Achaemenid glazed brick found at Susa, south-west Iran (mid-first millennium BC). Spectrochim Acta Part A Mol Biomol Spectrosc. 2013;116:49-56.

27. Hedges REM, Moorey PRS. Pre-Islamic ceramic glazes at Kish and Nineveh in Iraq. Archaeometry. 1975;17:25-43.

28. Askari-Chaverdi A, Callieri P, Gondet S. Tol-e Ajori, a new monumental building in Parsa. Preliminary cross interpretations from recent surveys and excavations works around Persepolis (2005-2012), ARTA. 2013: 1-40. [online available at http://www.achemenet.com/document/ ARTA_2013.006-Askari-Callieri-Gondet.pdf].

29. Mozaffari A. World heritage in Iran: perspectives on Pasargadae. London: Ashgate; 2015.

30. Wachowiak MJ. Efficient new methods for embedding paint and varnish samples for microscopy. J Am Inst Conserv. 2004;43(3):205-26.

31. Verri G, Collins P, Ambers J, Sweek T. Simpson SJ. Assyrian colours: pigments on a neo-Assyrian relief of a parade horse, British Museum Technical Research Bulletin, vol. 3. 2009. http://www.britishmuseum.org/PDF/ BMTRB\%203\%20Verri\%20et\%20al.pdf.

32. Kollmorgan Corporation. Munsell book of color, vol 1 and 2. Baltimore: Kollmorgen Corporation; 1966.

33. Kelly KL, Judd DB. Color: universal language and dictionary of names, NBS special publication 440. Washington: US Dept. of Commerce, National Bureau of Standards; 1976.

\section{Submit your manuscript to a SpringerOpen ${ }^{\circ}$ journal and benefit from:}

- Convenient online submission

Rigorous peer review

- Immediate publication on acceptance

- Open access: articles freely available online

- High visibility within the field

- Retaining the copyright to your article

Submit your next manuscript at $>$ springeropen.com 